\title{
INSECTICIDE PRACTICE FOR APHID CONTROL IN POTATOES
}

\author{
R.F. VAN TOOR and D.A.J. TEULON \\ Crop \& Food Research, Private Bag 4704, Christchurch, New Zealand
}

Corresponding author: vantoorr@crop.cri.nz

\begin{abstract}
Insecticide use for aphid control in potatoes by mainly Canterbury growers was assessed by a New Zealand-wide postal survey in 2001-02 and by examination of spray diaries from Canterbury (11 seed and 13 process growers) in 2003-04. Only 22\% (16 growers) of seed and 4\% (12 growers) of fresh potato growers responded to the postal survey, with Canterbury growers making up $93 \%$ of the respondents. Overall results indicate that most seed crops received a single seed/tuber treatment as well as approximately five foliar applications. Most process crops (2003-04 only) were seed/tuber treated with 0 or 1 foliar applications. For fresh crops (2001-02 only), 59\% were seed/tuber treated and 14\% had 2 or 6 foliar applications. Seed/tuber treatments were mostly imidacloprid but also phorate. Foliar applications included organophosphate, carbamate, synthetic pyrethroid and pyridine-azomethine insecticides. Insecticide use patterns are discussed in relation to the effectiveness of aphid/virus control and the risk of insecticide resistance.
\end{abstract}

Keywords: potato, aphid, virus, insecticide use, spray practices, grower survey, spray diaries, insecticide resistance.

\section{INTRODUCTION}

In New Zealand, insecticides are applied to potatoes to control potato tuber moth (Phthorimaea operculella) (Foot 1979) and several species of virus transmitting aphids, especially the green peach aphid (Myzus persicae) (Stufkens \& Teulon 2001). The requirement to keep potatoes, especially seed potatoes, virus free, necessitates a thorough and exacting aphid control programme often resulting in multiple insecticide applications. Insect control programmes that rely on the multiple use of the same or related insecticides can lead to insecticide resistance in the absence of insecticide resistance management strategies (Martin et al. 2005).

Insecticide resistance to aphids on potatoes has already been documented in New Zealand. Fellowes \& Fergusson (1994) considered that insecticide resistance was responsible for control failure of $M$. persicae in field trials in potatoes. Insecticide resistance was confirmed in $M$. persicae to selected organophosphates, carbamates and pyrethroids through laboratory studies (Cameron \& Walker 1988). Insecticide resistance has also been found in the melon aphid (Aphis gossypii) (Martin et al. 2005), another important virus transmitting pest of potato.

In response to these issues, the New Zealand potato industry, supported by the New Zealand Vegetable and Potato Growers Federation (now incorporated into Horticulture New Zealand), the agrochemical industry and other industry partners, initiated a project in 2002 to develop and implement a resistance management programme for aphids in potatoes. This project was supported through the Ministry for Agriculture and Forestry Sustainable Farming Fund. As part of this project, insecticide use in potato crops in New Zealand was documented.

In this paper insecticide use patterns are outlined for New Zealand potato crops established from a grower survey and through examination of selected grower spray 
diaries. These data provide a benchmark for future analysis of insecticide use in potatoes in New Zealand. Insecticide use is discussed in relation to aphid and virus management and the development of insecticide resistance in aphids.

\section{Postal survey: 2001-02 season}

\section{METHODS}

A postal survey (questionnaire) was sent to a selection of New Zealand potato growers registered with NZ Vegetable \& Potato Growers Federation, Wellington, in October 2002 to establish their practices (including insecticide usage) for managing viruses in potato for the 2001-02 season. Forty of the 74 seed potato growers, 15 of the 87 process growers and 45 of the 269 fresh potato growers were randomly selected using the statistical software package Genstat 4.2 (2002). Growers were asked about spray practice, such as when and what insecticides were used, how they were applied, cultural methods used for virus control, and the purpose for which the insecticides were used. Paddock size was not determined. A follow-up letter was sent to encourage a greater response at a later date.

\section{Spray diaries: 2003-04 season}

Spray diaries from Canterbury potato growers (written permission from each obtained), were accessed through McCain Foods Ltd, Washdyke, South Canterbury, and Alex McDonald Merchants, Darfield, Canterbury. Spray data from seed (11 growers with 10 growers under contract to one merchant, 11 paddocks) and process (13 growers, 84 paddocks) crops were obtained and examined. The timing of insecticide foliar applications in seed potatoes was compared with flights of aphids that colonise potatoes and vector viruses (M. persicae, M. euphorbiae, A. gossypii and A. solani). The aphids were collected weekly in a suction trap (7.5 m height) at Lincoln, within $30 \mathrm{~km}$ of the paddocks surveyed, and were identified to species level using standard taxonomic keys.

\section{Postal survey: 2001-02 season}

\section{RESULTS}

Twelve fresh growers and 16 seed growers responded, representing only $4 \%$ of the total fresh growers but $22 \%$ of the total seed growers in New Zealand. Fifteen of the seed growers were from the Canterbury region, where 66 of a total of 74 seed growers for New Zealand are located. Some respondents supplied information for multiple potato crops, so in total there were 22 and 31 paddocks for fresh and seed potato crops, respectively. No process growers responded to the postal survey. Of the total of 53 potato crops, $93 \%$ were grown in Canterbury; the others were in Pukekohe and Ohakune.

Seed producers. Of the 31 paddocks sown for seed, all except two paddocks contained seed treatments (Table 1). Phorate granules $\left(\right.$ Phorate $^{\circledR}$ ) were used at the label rate of $11 \mathrm{~kg}$ active ingredient (a.i.)/ha in three paddocks and at $15 \mathrm{~kg}$ a.i./ha in three paddocks, mainly to control aphids but also grass grub. The other 23 paddocks contained seed treated with imidacloprid $\left(\mathrm{Gaucho}^{\circledR}\right)$ to control aphids at the label rate of $54 \mathrm{ml}$ a.i./tonne seed (nine paddocks) or at the lower rate of $36 \mathrm{ml} \mathrm{a.i./tonne} \mathrm{seed} \mathrm{(14} \mathrm{paddocks).}$

Half of the number of paddocks that were treated with foliar insecticides received insecticides on a calendar basis and the other half were treated when aphids were found to be present. Only $13 \%$ of paddocks were treated for potato tuber moth as well as aphids. Of the 31 paddocks, $45 \%$ of paddocks received at least one foliar application of an organophosphate (acephate, dimethoate or methamidophos) or dimethyl carbamate (pirimicarb) at label rates to control aphids in potato foliage, while $16 \%$ of the paddocks received three or more sequential applications of an organophosphate or a carbamate. 
TABLE 1: Summary of postal survey showing insecticide use patterns for 31 seed potato crops during 2001-2002.

\begin{tabular}{|c|c|c|c|}
\hline \multirow{2}{*}{$\begin{array}{l}\text { No. } \\
\text { pdks }\end{array}$} & \multirow{2}{*}{$\begin{array}{l}\text { Seed } \\
\text { insecticide }\end{array}$} & \multicolumn{2}{|c|}{ Foliar insecticide (2001-2) } \\
\hline & & Active ingredient (no. applications) & Application dates (each paddock) \\
\hline 4 & None & & \\
\hline 10 & Imidacloprid & & \\
\hline 4 & Phorate & & \\
\hline 3 & Imidacloprid & Methamidophos ${ }^{1}(2)$ & $\begin{array}{l}\text { (18 Dec; } 6 \text { Jan) (14 Jan; } 4 \text { Feb) } \\
\text { (6, 25 Jan) }\end{array}$ \\
\hline 2 & Imidacloprid & Methamidophos (1) & $(18 \mathrm{Dec})(11 \mathrm{Feb})$ \\
\hline 1 & Phorate & Acephate $^{1}(1)$ & $15 \mathrm{Jan}$ \\
\hline 1 & Phorate & Dimethoate $^{1}(1)$ & $2 \mathrm{Feb}$ \\
\hline 1 & Imidacloprid & Pirimicarb $^{2}(1)$ & $19 \mathrm{Nov}$ \\
\hline 1 & Imidacloprid & Pirimicarb (5) & 21 Dec; 5, 16, 29 Jan; 9 Feb \\
\hline 1 & Imidacloprid & Pirimicarb (6) & 21 Dec; 5, 16, 29 Jan; 9, 22 Feb \\
\hline 1 & Imidacloprid & Methamidophos (3) & 11, 24 Jan; 11 Feb \\
\hline 1 & Imidacloprid & Methamidophos (3) \& acephate (1) & 7, 21 Dec; 6, 20 Jan \\
\hline 1 & Imidacloprid & Methamidophos (5) \& acephate (1) & 5, 14, 26 Jan; 7, 18 Feb; 4 Mar \\
\hline
\end{tabular}

Fresh producers. Thirteen of the 22 paddocks had seed treated with either phorate granules at the label rate of 11 (five paddocks), or 14 (two paddocks) and 18 (three paddocks) $\mathrm{kg}$ a.i./ha in the furrow, or imidacloprid (three paddocks) at the label rate of $54 \mathrm{ml}$ a.i./tonne seed to control aphids. The potato foliage in three of the 22 paddocks was sprayed with insecticides, with two paddocks receiving chlorpyrifos (Lorsban $50 \mathrm{EC}$ ) on $25 \mathrm{Jan}$ and $15 \mathrm{Feb}$ for control of aphids (also treated with phorate), and the other receiving methamidophos on 12 and 24 Jan, 4 and 18 Mar and 4 and $18 \mathrm{Feb}$ for control of potato tuber moth. The eight remaining paddocks received no insecticide treatments.

Spray diaries: 2003-04 season

Seed growers. All seed was treated with imidacloprid. The organophosphate methamidophos and the pyrethroid lambda-cyhalothrin were generally applied in sequence on more than two occasions (often more than five times, and up to nine times) (Table 2). Most paddocks received more than two sequential applications of insecticide belonging to one class of chemistry. Paddock sizes averaged 10 ha. The insecticides were mainly applied in 80-100 litre water/ha by aircraft.

The times of insecticide application by seed growers in Canterbury were superimposed upon data from Lincoln for the timing of flights of aphids that colonise potatoes and vector viruses. This showed that many sprays were applied in summer, between the peak aphid flights in spring and autumn (Fig. 1). 
TABLE 2: Summary of details from spray diaries for foliar insecticide applications to 11 Canterbury seed crops during 2003-04. All paddocks contained imidacloprid-treated seed.

\begin{tabular}{|c|c|c|c|}
\hline Paddock & Active ingredient & $\begin{array}{c}\text { No. } \\
\text { applns }\end{array}$ & Dates (2003-04) \\
\hline \multirow[t]{2}{*}{1} & pymetrizine $^{1}$ & 1 & $18 \mathrm{Dec}$ \\
\hline & methamidophos ${ }^{2}$ & 5 & 1, 15, 28 Jan; 6, 16 Feb \\
\hline \multirow[t]{2}{*}{2} & pymetrizine & 1 & $19 \mathrm{Dec}$ \\
\hline & methamidophos & 9 & 26 Dec; 5, 17, 26 Jan; 6, 17 Feb; 1, 10, 16 Mar \\
\hline \multirow[t]{2}{*}{3} & pymetrizine & 1 & 19 Dec \\
\hline & methamidophos & 9 & 26 Dec; 5, 17, 26 Jan; 6, 17 Feb; 1, 10, 13 Mar \\
\hline 4 & methamidophos & 6 & $31 \mathrm{Dec} ; 13$, 23 Jan; 4, 16 Feb; 1 Mar \\
\hline \multirow[t]{2}{*}{5} & pymetrizine & 1 & $19 \mathrm{Dec}$ \\
\hline & methamidophos & 6 & 31 Dec; 11, 22 Jan; 2, 12, 26 Feb \\
\hline 6 & methamidophos & 4 & 5, 17 Feb, 1, 16 Mar \\
\hline \multirow[t]{2}{*}{7} & lambda-cyhalothrin ${ }^{3}$ & 1 & $24 \mathrm{Mar}$ \\
\hline & methamidophos & 6 & 27 Jan; 6, 16, 26 Feb; 8, 18 Mar \\
\hline \multirow[t]{2}{*}{8} & lambda-cyhalothrin & 3 & $23 \mathrm{Feb} ; 4,15 \mathrm{Mar}$ \\
\hline & methamidophos & 4 & 21, 30 Jan; 9, 19 Feb \\
\hline \multirow[t]{2}{*}{9} & lambda-cyhalothrin & 3 & 27 Feb; 13, 22 Mar \\
\hline & methamidophos & 5 & 27 Jan; 6, 16, 26 Feb; 8 Mar \\
\hline \multirow[t]{3}{*}{10} & lambda-cyhalothrin & 2 & 1, $6 \mathrm{Mar}$ \\
\hline & pymetrizine & 3 & 27 Dec; 22 Jan; 2 Feb \\
\hline & methamidophos & 3 & 10 Jan; 12, 22 Feb \\
\hline 11 & dimethoate $^{2}$ & 5 & 20, 30 Dec; 10, 14, 17 Jan \\
\hline
\end{tabular}

${ }^{1}$ Chemical group $=$ pyridine-azomethine.

${ }^{2}$ Chemical group $=$ organophosphate .

${ }^{3}$ Chemical group $=$ pyrethroid.

Process growers. All of the 84 paddocks were sown with insecticide-treated potato seed, with $98 \%$ being treated with imidacloprid and $2 \%$ with phorate. Forty-two percent of paddocks received no foliar insecticide application. The other paddocks received one (42\%), two (10\%) or three (6\%) applications of foliar insecticides. Those paddocks with one application received methamidophos, dimethoate, lambda-cyhalothrin or pirimicarb in mid-to-late December to control aphid populations (after the insecticidal effects from imidacloprid had attenuated). For the paddocks with two applications, $6 \%$ had two applications of lambda-cyhalothrin and $4 \%$ had two applications of methamidophos. For the paddocks with three applications, $4 \%$ had one application of pirimicarb and two of lambda-cyhalothrin and $2 \%$ of paddocks received three sequential applications of lambda-cyhalothrin. Insecticides were applied mainly in 200-400 litre water/ha by truck or tractor. 


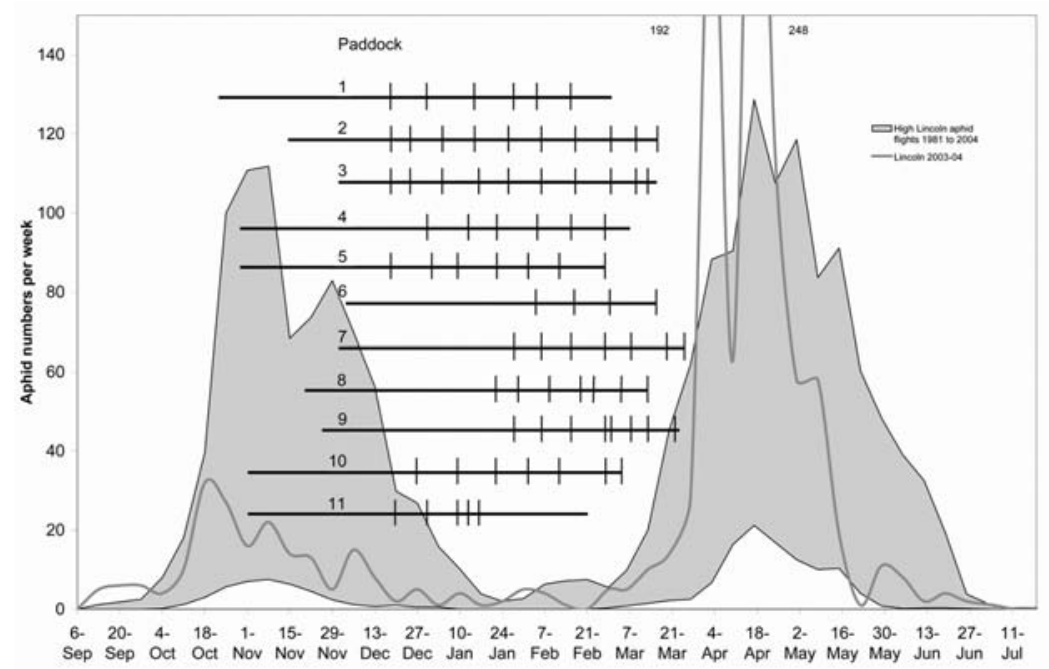

FIGURE 1: Times of insecticide application to control aphids on potatoes during 2003-04 in 11 paddocks. Horizontal lines represent the period between planting and final desiccation for each paddock while vertical bars on these indicate the application times of insecticides. Also shown are the numbers/week of potato-colonising aphids (M. persicae, $M$. euphorbiae, $A$. gossypii and $A$. solani) caught at the Lincoln suction trap over 23 years (66\% percentile in gray shading) and during 2003-04 (solid line).

\section{DISCUSSION}

North Island growers were not represented for comparisons on insecticide methods/ attitudes between North and South Islands due to a low response in the postal survey (2001-2002 season) and a merchant not supplying permission to use their spray diaries in the 2003-04 season. However, the results of the survey and examination of spray diaries gave a measure of insecticide use on potatoes in Canterbury in the past five years. The total numbers of seed, fresh and process potato growers in Canterbury represented 89,53 and $49 \%$ of the total growers within their respective categories in New Zealand (R. Gall, pers. comm.), and therefore the results also gave a measure of insecticide use in New Zealand. Most seed crops received a single seed or tuber treatment as well as several (range 0-10 but averaging five) foliar applications. Process crops (2003-04 figures only) were also mostly seed or tuber treated but had considerably fewer foliar applications (usually none or one) than seed crops. Only 59\% of fresh crops (2001-02 figures only) were seed or tuber treated, and there were mostly no foliar applications. To place this insecticide use in context of land use there were about 1200 ha of seed, 6000 ha of process and 4274 ha of fresh potatoes grown in New Zealand in 2003-04 (R. Gall, pers. comm.).

There was a very low response from fresh growers to the postal survey so these figures should be used with caution. The intensity of insecticide use probably reflects the end-use of the crop, with a requirement for virus-free seed potatoes, in particular, and unblemished tubers for processing. In comparison there is a greater tolerance of virus infection and blemishes for fresh crops. As data were only available for seed potato crops in both instances, comparisons between process and table crops between the two assessments 
cannot be made. For seed potatoes, there was a much greater range of insecticide strategies reported from the postal survey than in the spray diaries. The postal survey represented individual respondents whereas the spray diaries were restricted to growers that followed spray programmes largely prescribed by two commercial companies. The other major difference between the two studies was that there was a greater use of insecticides reported in the spray diaries, possibly reflecting an increase in insecticide use between 2001-02 and 2003-04.

The response from the postal survey was disappointing. There were responses from only $22 \%$ of seed, $0 \%$ of process and $4 \%$ of fresh potato growers. A similar survey of arable growers in relation to aphids/barley yellow dwarf virus control had a response rate of $24 \%$ (Greer \& Teulon (2003). These authors considered arable growers to be reluctant participants in postal surveys and it appears that a similar conclusion could be drawn for potato growers. Another possible reason for the low response rate to the potato survey was that it was carried out by plant protection personnel. A higher response rate would be expected if the survey was conducted by a survey specialist experienced in ensuring representative participation rates (S. Singley, pers. comm.). Nevertheless, this study indicates that the examination of spray diaries, with prior permission from participating growers, appears to be a much more effective means for obtaining accurate pesticide use data.

The comparison of foliar applied insecticides to seed crops with aphid flights in 2003-04 indicates that many insecticides were applied to crops during periods of relatively low aphid flight activity (Fig. 1). In separate surveys of Canterbury potato seed crops in 2002-03, 2003-04 and 2004-05 (23-35 paddocks per year), an increasing incidence of potato leaf roll virus (PLRV) (4, 3 and 17\% of paddocks with infected plants in each year, respectively) and potato virus $Y$ (PVY) (20, 44 and $43 \%$ of paddocks with infected plants in each year, respectively) was found (J. Fletcher, pers. comm.). The estimated virus incidence within these crops ranged from 1-17\% for PLRV and 1-20\% for PVY, apart from two crops that recorded $100 \%$ incidence, one for PVY and one for PLRV. These figures suggest that current management programmes for aphid/virus control in potatoes, including insecticide use, are not providing adequate control of aphids and the viruses they transmit. The presence of aphids/viruses on crop re-growth after plant desiccation late in the season has been highlighted as one time when potatoes are at increased risk of virus transmission (Stufkens \& Teulon 2001). Furthermore, recent evidence suggests that not all insecticides are equally effective in reducing the incidence of PLRV in potatoes (Mowry 2005). The organophosphate, methamidophos, and the carbamate, oxamyl, were relatively ineffective in reducing transmission of PLRV from infected to healthy potato plants by $M$. persicae, whereas the chloronicotinyl, imidacloprid, and the pyridine azomethine, pymetrozine, were highly effective. The synthetic pyrethroid, esfenvalerate, was effective in reducing inoculation of PLRV by virus-infected aphids into potatoes due to its repellent effect, but not virus acquisition by aphids from infected plants (Mowry 2005). Insecticides are less effective in controlling PVY infection, because the PVY is non-persistent and borne on the aphid's stylet, and may be transmitted before the aphid is killed.

The development of insecticide resistance by an insect pest can cause severe disruption to crop protection and production. Evidence of aphid resistance to insecticides in potatoes has been previously documented (Cameron \& Walker 1988; Fellowes \& Fergusson 1994; Martin et al. 2005) and recent research has detected resistance mechanisms in Myzus persicae clones collected from potatoes throughout New Zealand. van Toor et al. (2005) found that between late summer and early autumn of $2005,66 \%$ of the clones contained at least one mechanism of resistance to four of the five insecticide groups used on potatoes (organophosphates, carbamates, synthetic pyrethroids and neonicotinoids). In some cases up to four mechanisms were found in a single clone.

Extensive, repeated and sequential use of a single class of insecticides is a strong positive risk factor for the development of insecticide resistance (Martin et al. 2005). The insecticide use patterns for potato crops in New Zealand detailed above suggest 
two areas where strategies to delay the development of aphid insecticide resistance would be beneficial. Firstly, seed treatments of imidacloprid were identified as being used extensively in potato seed and process production and to a lesser extent in fresh production. Additionally, imidacloprid is used extensively for aphid control in wheat, lettuce, etc. (James et al. 2004, G. Walker, pers. comm.) in New Zealand. Secondly, methamidophos was identified as being used sequentially and repeatedly in seed crops. Also, the common practise of applying insecticides from the air at low water rates (80-100 litre water/ha) may not be sufficient to ensure adequate penetration of the insecticide into dense foliage late in the season, inadvertently supplying a sub-lethal dose. van Toor (2005) has recently recommended two insecticide resistance management strategies for aphids in New Zealand potato crops to target these potential problems. One is a knowledge-intensive system involving application of insecticides based on the risk of aphid infestation and virus infection. The other involves strategic use of different insecticide classes at different times of the cropping season. The later recommendations have been implemented in parts of the potato industry (D. McLeod, pers. comm.) and the potato industry is currently examining ways to implement effective insecticide resistance management strategies more fully through additional technology transfer programmes (R. Gall, pers. comm.).

\section{ACKNOWLEDGEMENTS}

The authors thank all the potato growers who supplied information on insecticide usage and acknowledge MAF Sustainable Farming Fund, Horticulture New Zealand, Syngenta, McCain Foods, Alex McDonald Merchants and the New Zealand Foundation for Research, Science and Technology for funding aspects of this work.

\section{REFERENCES}

Cameron PJ, Walker GP 1988. Insecticide resistance in green peach aphid from South Auckland. Proceedings of the 41st New Zealand Weed and Pest Control Conference: 85-89.

Fellowes RW, Fergusson AM 1994. Field evidence for resistance to certain insecticides to green peach-potato aphid in South Auckland. New Zealand Journal of Experimental Agriculture 2: 83-88.

Foot MA 1979. Bionomics of the potato tuber moth, Phthorimaea operculella (Lepidoptera: Gelechiidae), at Pukekohe. New Zealand Journal of Zoology 6 (4): 623-636.

Greer G, Teulon DAJ 2003. Farmer survey of yellow dwarf viruses in autumn sown cereals in Canterbury. New Zealand Plant Protection 56: 257-261.

James DE, Fletcher CD, Teulon DAJ 2004. Insecticide use patterns for aphids and virus in autumn sown cereals in Canterbury. New Zealand Plant Protection 57: 340.

Martin NA, Beresford RM, Harrington KC 2005. Pesticide Resistance: Prevention and Management Strategies 2005. New Zealand Plant Protection Society, Hastings, New Zealand. 225 pp.

Mowry TM 2005. Insecticidal reduction of Potato leafroll virus transmission by Myzus persicae. Annals of Applied Biology 146(1): 81-88.

Stufkens MAW, Teulon DAJ 2001. Aphid species on potato crops in Canterbury. New Zealand Plant Protection 54: 235-239.

van Toor RF 2005. Potato aphid insecticide-management strategy. Crop \& Food Confidential Report No. 1506, Crop \& Food Research, Lincoln New Zealand. (Used with permission from Horticulture New Zealand.) $36 \mathrm{pp}$.

van Toor RF, Foster SP, Anstead JA, Mitchinson S, Cox D, Barnes A-M 2005. High proportion of Myzus persicae on potatoes in New Zealand with insecticide resistance mechanisms. 7th International Aphid Symposium, Fremantle, Western Australia. p. 36. 